\title{
MARKET DISCIPLINE MECHANISM: A QUANTITATIVE APPROACH (THE STUDY OF ISLAMIC BANKING IN INDONESIA 2011-2014)
}

\author{
Ayub Wijayati Sapta Pradana *) \\ Hariri **) \\ Junaidi $* * *$ )
}

\begin{abstract}
Transparency of information are the main requirement of market discipline mechanism which is described by an adequate disclosure. Through the quantitative approach, the customer will attract an investment funds (giro, savings, deposits) if the bank takes a high risk action based on information that disclosed on financial statements. In a theoretical view, Islamic banks with the principle of profit-loss sharing (PLS) have a higher risk than conventional banks with a fixed rate of interest, so that customers of Islamic banks should have a higher sensitivity than conventional bank customers. The next question, whether the customers of Islamic banks would react to the disclosure of financial statements through changes in the number of funds invested?

This research aimed to examine the effect of the level of disclosure of financial statements to changes in the number of third party funds in Indonesia Islamic Banking on the period 2011-2014. Data were analyzed using a regression model. The study states that the level of disclosure of financial statements significant positive effect on changes in the number of third-party funds were indicates that there is a mechanism of market discipline on Islamic Banks in Indonesia. However, this result must to be strengthened by data of risk disclosure and ability to absorb information from customers, analysis of determinants were affecting customers behavior, then as well as the comparison test with conventional commercial banks.
\end{abstract}

Keywords: Market Discipline, The Level of Disclosure, Third Party Funds, Islamic Bank

\section{INTRODUCTION}

\subsection{Research Background}

Good description of the growth and development of Islamic banking (iB) in Indonesia (Bank Indonesia, 2014) have to be accompanied by the implementation of Good Corporate Governance for Islamic banking which transparency is the main pillar (Bank Indonesia Regulation Number 11/33 / PBI / 2009). Another words, transparency is an absolute necessity in the world of banking in particular and general economic. But the reality today illustrates the opposite, which is visible from some of large accounting scandals in the world, such as Enron (in 2001), WorldCom (in 2002), and recently Lehman Brothers (in 2008) then have contribution to subprime mortgage USA 2008 may causes by a lack of disclosure or over-understatement information by the company (Shehata, 2014).

Simillar to the situation in the world, transparency in Indonesia also remained at a low level. In auditing and reporting area, Indonesia has 74th out of 148 countries (The Global Competitiveness Report 2013-2014). The results of Pricewaterhouse and Coopers survey of investors in Asia also shows that Indonesia has a low rank in transparency, disclosure standards and practices and the application of auditing, compared to other Asian countries and Australia (FCGI 2004 in Nuryaman, 2008). Those facts force Indonesia to increase transparency (disclosure level) of financial statements as well as the implementation of auditing standards and effective reporting.

In Islamic banking, the issue of transparency is also a major concern of customers and other interested parties (Nurhayati and Wasilah, 2013). Lahrech et.al (2014) explains that transparency in Islamic banks with the terms of profit sharing distribution and placement of funds in customer deposits (investment account-holders) are not sufficient. Arifin et.al (2005) describes a perceptional by empirical research on issues of transparency and market discipline in Islamic banks from 14 countries showed that 
transparency and disclosure of risks are unoptimal. Some of these phenomena, raises critical questions about the transparency (disclosure level) as well as the role of accounting which produce high quality of financial information on Islamic banks.

Transparency in this study specifically refers to the level of disclosure in the financial statements. Hidayat and Abdulrahman (2014) examined the level of disclosure of the annual report on the fifth Islamic bank in Bahrain period in 2010 shows that that the Islamic bank has a high level of compliance to the AAOIFI standards. Al-Sawalqa (2014) also did research on the level of compliance with corporate governance mechanism in the aspects of transparency and disclosure as well as comprehensive voluntary disclosure on 13 banks in Jordan listed in the Amman Stock Exchange (ASE) in 2012, the results showed that mandatory disclosure of Islamic banks is very high, but it is not accompanied with the same level of voluntary disclosure.

Several studies in middle eastern countries are taking the level of compliance of banks as the object of study, but the standards used such as AAOIFI standards and corporate governance mechanis just referring to generally sector. While in this study, has been using special accounting standards for financial statement disclosure of Islamic banking. In addition, high levels of Islamic bank disclosure of research results from Abdulrahman Hidayat (2014) and Al-Sawalqa (2014) has not specially explain on bank risk aspect, thus contradict research from Lahrech et.al (2014) and Arifin et.al (2005).

Recently, research on the level of disclosure of financial statements in Indonesia both mandatory and voluntary disclosure (Gray, et.al, 1995) have not been focused on the banking sector but in other sectors, namely: financing about to 79.56\% (Oktaviani and Martani, 2006), manufacturing 64.75\% (Primastuti and Achmad, 2012), property and real estate about to 57.24\% - 77.45\% (Agustina, 2012; Permata, 2013), about to 30.85\% of government - 37.92\% (Subkhan and Luthfiyati 2011; Suhardjanto and Yulianingtyas, 2011), and other sectors ranged from 34.32\% to $58.87 \%$ (Nuryaman 2008; Hardiningsih 2008; Hapsoro, 2009; Wardani, 2012; Baskaraningrum and Merkusiwati, 2013).

An adequate disclosure of financial statements make customers get information about the performance and risks of banks (Hosono, 2005; Stephanou, 2010; Febrian and Herwany, 2011). Customers will respond by withdraw deposits (quantitative approach) or set a high interest (price approach) in a bank that has a high risk, it is referred to as market discipline mechanism (Levi-Yeyati et.al, 2004; Hosono, 2005; Febrian and Herwany, 2011). Islamic banks with the principle of sharing will give the consequences of risk acceptable result customers are higher than conventional banks (Hasan, 2013), so it indicate that customers sensitivity on Islamic banks is higher than conventional bank customers (Hasan and Tandelilin, 2012). However, whether customers of Islamic banks with no fixed acceptance will react to the information were disclosed in the financial statements by attracting deposits? Based on those explanation, in market discipline mechanism frame with a quantitative approach, this study tries to formulate a relationship between the level of disclosure of financial statements with changes in the number of third-party funds (giro, saving, deposits) in Islamic banks.

\subsection{Research Problem}

The research problem is whether customers of Islamic banks with no fixed acceptance will react to the information were disclosed in the financial statements by attracting deposits?

\subsection{Research Purpose}

This research aims to know and examines customers of Islamic banks with no fixed acceptance will react to the information were disclosed in the financial statements by attracting deposits.

\section{THEORETICAL FRAMEWORK}

\subsection{Theoretical Framework}

\subsubsection{Sharia Enterprise Theory}

Theory of sharia within the scope of corporate accounting will initially be directed to the concept of vertical accountability and continuing through the implementation of the concept of horizontal accountability (Triyuwono, 2006: 340-341). The concept of vertical accountability explains that God as 
the Ultimate Principal assigns human (agents) to spread the grace and welfare (in the form of economic, social, spiritual, political and so on) to another human being (stakeholders) and nature (natural environment) (Triyuwono and Roekhudin, 2000: 157-164 in Triyuwono, 2006: 340). Furthermore, the human task must be applied in life so the agent (management) should be responsible to society (stakeholders) and nature (universe), is called horizontal accountability (Triyuwono and Roekhudin, 2000: 157-164 in Triyuwono, 2006: 341 ). Company has an obligation as a responsible agent vertically to God and horizontally to stakeholders and nature through the disclosure and presentation of corporate information in a fair, transparent, full disclosure, and not favoring one particular group. In other words, all parties get access to information about the company's decision-making.

\subsubsection{Stakeholders Theory}

Stakeholder theory described that group of people or individuals can influence the company's activities or may be affected by the activities of the company, either directly affect the company (primary stakeholders) such as the owner-shareholder-investors, managers and employees, customers or clients, local communities and other business partners, and indirectly affect the company (secondary stakeholders) such as government, civil organizations, social groups, media and academia, as well as business competitors (Freeman, 1984). These linkages will lead to consequences that companies need to implement responsibilities to stakeholders and to implement good corporate governance (GCG), which is expected to meet the interest of stakeholders (Deegan, 2000). Transparency as a major pillar of good corporate governance can be realized by relevant and adequate disclosure for stakeholders (Arifin et.al, 2005; Hosono, 2005; Stephanou, 2010; Febrian and Herwany, 2011). Disclosure is a form of corporate responsibility to the stakeholder to reduce asymmetry information between the two sides (Deegan, 2004: 267), so it can be support the process of rational economic decision. With the disclosure of stakeholders can minimize losses due to errors in economic decisions.

\subsubsection{Market Discipline Theory}

Basel Committee on Banking Supervision (2001) determined the three pillars of efforts to improve health and safety (safety and soundness) of banks in the financial system, namely; 1) market discipline, 2) minimum capital standards, 3) regulatory process for the regulator. Market discipline is one of the pillars of the three elements that complement each other in order to realize the banking world a healthy and safe.

Stephanou (2010) defines market discipline as a mechanism which market participants can monitor and discipline the behavior of excessive risk-taking by banks. This is in line with the arguments put forward by Levi-Yeyati et.al (2004), Hosono (2005), as well as Febrian and Herwany (2011).

Disclosure of information (transparency) is the first aspect in the framework of market discipline (Stephanou, 2010; Hasan, 2013). By the disclosure, market participants can process the information, and oversight of the bank so that there will be market discipline mechanism. Halamainen et.al $(2003,2005)$ and Hasan (2013) also added that transparency should be present in effective market discipline.

The principle of revenue sharing on Islamic banks that do not give fixed revenue will give impact in the risk acceptance for customers is higher than conventional bank (Hasan, 2013). The results of empirical research by Hasan and Tandelilin (2012) uses the data of annual financial reports from 120 conventional and Islamic banks 2005-2009 were indicate that market discipline by depositors of Islamic banks is more powerful than depositors of conventional banks. Reaction depositors in Islamic banks are stronger because they are facet to the higher risk acceptance as a consequence of the principle of profit and loss sharing (Hasan and Tandelilin, 2012; Hasan, 2013).

Levi-Yeyati et.al (2004) states that the reaction of depositors on the bank's risk can be seen through two types of approach; 1) a quantitative approach (withdraw deposits), and 2) price approach (set interest rates or for a high yield). Especially for this study is more relevant to look at the reaction of the market (market power) using a quantitative approach that can be observed on the fluctuations of changes in the number of third party funds in period of research. 


\section{RESEARCH METHOD}

\subsection{Research Design}

Descriptive research is used to analyze and present data that is quantitative research. Levels of disclosure (Y) as the independent variable is measured by an index referred to the disclosure from Wallace, et.al (1994) as well as a combination mandatory disclosure and voluntary disclosure. Item of mandatory disclosure made by PAPSI 2003 (Attachment 1), while the voluntary items (Attachment 2) refers to the instruments developed by Al-Baluchi (2006) which was adapted the items already included in PAPSI 2003 was not put back in the item voluntary disclosure. Changes in the number of third party funds (Z) as the dependent variable is measured by the difference between third party fund current period $(t)$ with third party funds the previous period (t-1) in the form of the natural logarithm (Levy-Yeyati, 2004; Hasan and Tandelilin 2012 ). The third party funds of islamic banks in this study refers to the DSN MUI fatwa no. 1-3 Th 2000 which consist of giro, savings, deposits of mudharabah.

Table 1 Research Variables and Indicator

\begin{tabular}{|c|c|c|c|}
\hline Variable & Variable & Indicator & Scale \\
\hline $\begin{array}{l}\text { Level of } \\
\text { Disclosure } \\
\text { (Y) }\end{array}$ & $\begin{array}{l}\text { Disclosure Index (DI) } \\
\text { The number of disclosure items } \\
\text { disclosed by the company } \\
\text { (mandatory and voluntary } \\
\text { disclosure) in the financial } \\
\text { statements. (Wallace, et.al, 1994) }\end{array}$ & $\begin{array}{l}\qquad \frac{n}{k} \times 100 \% \\
\mathrm{n}: \text { the number of mandatory } \\
\text { and voluntary disclosure items } \\
\text { disclosed } \\
\mathrm{k}: \text { the number of mandatory } \\
\text { and voluntary disclosure items } \\
\text { are set to be revealed }\end{array}$ & Ratios \\
\hline $\begin{array}{l}\text { Changes of Third } \\
\text { Party Funds } \\
\text { (Z) }\end{array}$ & $\begin{array}{l}\Delta \text { Third Party Funds }(\triangle D P K) \\
\text { Changes (increase or decrease) } \\
\text { the number of public deposits in } \\
\text { the form of giro, savings and } \\
\text { deposits mudharabah from } \\
\text { current period against the } \\
\text { previous period. } \\
\text { (Levy-Yeyati, 2004; Hasan and } \\
\text { Tandelilin, 2012) }\end{array}$ & $\begin{aligned} \text { Ln } & \Delta \text { Third-party Funds (DPK) } \\
& =\operatorname{Ln}\left(\mathrm{DPK}_{(\mathrm{t})}-\mathrm{DPK}_{(\mathrm{t}-1)}\right)\end{aligned}$ & Ratios \\
\hline
\end{tabular}

\subsection{Population and Sample}

Unit of analysis are Islamic Banks (BUS) in Indonesia (Attachment 3). Population (Sekaran, 2003: 59) in this study was the annual financial statements of BUS in Indonesia with the consistency of data acquisition during the study period of 2011-2014 then obtain 11 BUS. The sampling technique used is saturated sampling that all members of the population were used as a sample of 44 annual financial statements (Sugiyono, 2011: 68), so the data is combination of cross-sectional data and time-series data. This type of data is secondary data obtained from official official website BUS in Indonesia by means of documentation and then analyzed one by one in order to obtain the relevant data.

\subsection{Data Analysis}

Data analysis method used was simple linear regression model (simple regression) Testing of hypothesis on the causal model or Ordinary Least Square (OLS) can be applied to the analysis of the model separately, the variable $\mathrm{Y}$ affects $\mathrm{Z}$, but $\mathrm{Z}$ does not affect $\mathrm{Y}$ thus showing unilateral causal dependence. Previous first tested the normality and classical assumption (heteroscedasticity and autocorrelation). The research model as follows: 


$$
Z=\beta_{0}+\beta Y+e
$$

\footnotetext{
Where:

$\mathrm{Z}=$ Change of Third Party Funds

$\beta 0=$ constant (intercept)

$\beta=$ coefficient of regression

$\mathrm{Y}=$ Level of Financial Statements

$\mathrm{e}=$ error
}

The hypothesis is:

H0: $\beta \leq 0$, meaning that the level of disclosure of financial statements no significant positive effect on $\Delta$ third party funds.

Ha: $\beta>0$, meaning that the level of disclosure of financial statements $\Delta$ significant positive effect on third-party funds.

Testing of hypothesis partially ( $\mathrm{t}$ test) test using the right side, with the following criteria:

Ho can not be rejected if $\mathrm{t} \leq \mathrm{t}$ table or sig $>0.05$, Ho can be rejected if $\mathrm{t}>\mathrm{t}$ table or sig $<0.05$

\section{RESEARCH RESULT AND ANALYSIS}

\subsection{Descriptive}

The general picture that are in the highest level of disclosure of Bank Syariah Mandiri and Bank Indonesia Muammalat by $71 \%$, while Maybank Syariah was lower by $56 \%$ (Appendix 4). The average index of mandatory disclosure of bank Muammalat highest in 71\%, while Bank Mega Syariah recorded the lowest value of 46\% (Appendix 5). Bank Syariah Mandiri has the highest level of voluntary disclosure of which is equal to $80 \%$, while Maybank Syariah re-recorded with the lowest value of $63 \%$ (Appendix 6). Changes in the number of third party funds (DPK) is the highest in the Bank Syariah Mandiri with an average $\triangle \mathrm{DPK}$ amounted to 9.15 trillion rupiah, while the lowest was Maybank Syariah $\triangle \mathrm{DPK}$ with an average of 0.21 trillion rupiah (Appendix 7). Results Descriptive statistics of the variables are as follows:

Table 2 Results of Descriptive Statistics

\begin{tabular}{|l|c|c|c|c|c|}
\hline & $\mathrm{N}$ & Minimum & Maximum & Mean & $\begin{array}{c}\text { Std. } \\
\text { Deviation }\end{array}$ \\
\hline Y (DI) & 44 & 54,13 & 72,39 & 62,4490 & 4,62644 \\
Z (LnDPK) & 44 & 22,33 & 30,24 & 27,5588 & 1,59568 \\
Valid N (listwise) & 44 & & & & \\
\hline
\end{tabular}

Source: data were processed using SPSS ver 20

Variable rate of disclosure or disclosure index (Y) shows that the lowest value is 54,13, namely Maybank Syariah in 2011, while the highest value is 72.39, Bank Muamalat Indonesia in 2013, and the average value is 62.4490. Standard deviation of 4.62644 so if it happens deviation is no more than 4.62644 or 4.62644. Variable Ln DPK (Z) shows that the lowest value is 22.33 which is Maybank Syariah in 2011, while the highest value is 30.24, Bank Syariah Mandiri in 2011 and the average value is 27.5588. Standard deviation of 1.59568, which means if there is deviation is the average then no more than 1.59568 or -1.59568 .

Normality of the data was tested with Kolmogorov-Smirnov test showed the results of the p-value $(\mathrm{sig})=0.911$ greater than 0.05 , which means that the distribution of the data has to meet the assumptions of normality (Attachment 8). While the residual value of the estimated regression results also have to meet the assumption of normal distribution as indicated by the spread of data around a diagonal line on the graph-Normal Probability Plots (Appendix 9). The pattern of the spread of residual regression equations on a graph Scetter plot shows that the points do not form a particular pattern and dots spread 
above and below the number 0 (zero) on the $\mathrm{Y}$ axis, the model is homoskedastik or not there is a problem of heteroscedasticity (Appendix 10). Autocorrelation test is indicated by the value of Durbin Watson of DW $=1.691$ (Appendix 11) which is in the area hesitation (Appendix 12), so it is necessary to continue with the test Run test to determine the randomness of the error value regression model and obtained sig Run test $0.996>0,05$ which means that the value of residual random or it can be concluded there is no autocorrelation problem for the regression model used (Appendix 13).

\subsection{Research Discussion}

Table 3 Coefficient $\mathrm{Y}$ to $\mathrm{Z}$

\begin{tabular}{|ll|l|l|l|l|l|}
\hline \multirow{2}{*}{ Model } & \multicolumn{2}{|l|}{$\begin{array}{l}\text { Unstandardized } \\
\text { Coefficients }\end{array}$} & $\begin{array}{l}\text { Standardized } \\
\text { Coefficients }\end{array}$ & \multirow{2}{*}{ Tig. } \\
\cline { 2 - 5 } & $\mathrm{B}$ & Std. Error & Beta & \\
\hline $\begin{array}{lllll}\text { (Constant) } \\
1\end{array}$ & $\begin{array}{l}\text { Y_hat(Unstandardized } \\
\text { Predicted Value) }\end{array}$ &, 366 & 1,796 & & 2,607 &, 014 \\
\hline
\end{tabular}

a. Dependent Variable: Z (LnDPK)

Source: data were processed using SPSS ver 20

From the table above can be the result of a simple linear regression equation for the effect of the level of disclosure to $\triangle \mathrm{DPK}$ is $\mathrm{Y}=4.683+0.366$ constants obtained from the equation (intercept) of 4.683 which means $\triangle \mathrm{DPK}$ without the influence of any factor is equal to 4.683 . The regression coefficient disclosure level $(\mathrm{Y})$ is positive, amounting to 0.366 , which means if the disclosure level of $1 \%$, then $\Delta \mathrm{DPK}$ will increased by $0.366 \%$. So the higher the level of disclosure will be followed by a rise of $\Delta \mathrm{DPK}$. To determine whether there is a direct influence on the level of disclosure $\triangle \mathrm{DPK}, \mathrm{t}$ test analysis carried out by setting a confidence interval of $95 \%$ or $\alpha=5 \%$.

Table 4 Tabel Coefficient ( $\mathrm{t}$ test)

\begin{tabular}{|c|r|r|r|r|r|}
\hline \multirow{2}{*}{ Model } & \multicolumn{2}{|c|}{$\begin{array}{c}\text { Unstandardized } \\
\text { Coefficients }\end{array}$} & $\begin{array}{c}\text { Standardized } \\
\text { Coefficients }\end{array}$ & & \multirow{2}{*}{ Sig. } \\
\cline { 2 - 5 } & & Std. Error & Beta & & \\
\hline (Constant) &, 683 & 1,796 & &, 607 & 014 \\
Y_hat(Unstandardized Predicted Value) & 366 &, 029 &, 917 & 2,761 & 000 \\
\hline
\end{tabular}

a. Dependent Variable: Z (LnDPK)

Source: data were processed using SPSS ver 20

This study examined the correctness of the return market discipline described by Stephanou (2010) related customer response $(\triangle \mathrm{DPK})$ on the level of disclosure. According to Stephanou (2010) transparency of company information which is indicated by the level of disclosure is the main condition the market discipline mechanism, it is in line with that expressed by Arifin et.al (2005), Hosono (2005), Febrian and Herwany (2011), as well as strengthened with the opinion of Halamainen et.al (2003, 2005) and Hasan (2013) which mentions transparency as a condition of effective market discipline mechanism. Lachrech et.al (2014) adds that the increase in transparency will lead to improved governance of investment fund clients by Islamic banks and avoid the practice of allocation of benefits that are not in favor of the customer.

Market participants will absorb the information that disclosed from bank primarily related to performance and risk, and will give the same response using quantitative approach to attract deposits if high risk or otherwise low performance (Levy-Yeyati et.al, 2004) are illustrated through. Respon changes 
has been describe by increase or decrease the number of third-party funds ( $\triangle D P K)$. A quantitative approach is more often used in research because it can be directly observed by fluctuations of DPK and demonstrate the market power of customers.

Hasan and Tandelilin (2012) using the change in the number of deposits (the dependent variable) as a proxy for market discipline in t period to the financial risks of banks as a variable independent in t-1 period to detect market discipline Islamic banks and conventional banks in Indonesia before and after the global crisis. The results showed a stronger market discipline in the past before the crisis (2005-2007) than during the crisis and its aftermath (2008-2009). Similar disclosed by Taswan (2011), which examines market discipline as a control banking risks found that there is a mechanism of market discipline in Indonesia either when deposit guarantee implicit or explicit, so that it can be concluded that the decision of depositors purely influenced because of the bank's risk is high and not due to the guarantee scheme.

In the context of empirical studies of Islamic banking, this research also supported by Hasan and Tandelilin (2012) which states that the practice of market discipline in Islamic banks are stronger than conventional banks. This is in line with empirical research perceptional Arifin et.al (2005), which outlines the level of risk disclosure Islamic banks should be higher than conventional banks, as well as reinforced with theoretical arguments of Hasan (2013) which explains that risk acceptable result is greater islamic bank customers rather than risk an acceptable result of conventional bank customers related to the concept of profit sharing (profit loss sharing) as the main principles of sharia bank operations with the consequences of not fixed receiving income. This study therefore indicates the market discipline mechanism occurs in the BUS in Indonesia during 2011-2014. The mechanism shown through significant positive effect on the level of disclosure to the market response in the form of $\triangle D P K$ which means that the higher the level of disclosure of the higher $\triangle \mathrm{DPK}$.

Other studies on market discipline is also done by Jatna (2007) and Valensi (2005) however showed different results. Research carried out in some groups of conventional commercial bank in Indonesia, Jatna (2007) concluded that there has been no effectiveness in market discipline. This is due to the low understanding of the financial statements of banks and limited access to information about performance of individual banks.

Valensi (2005) test for the presence of market discipline by depositors and fellow bank (peer-banks) in Indonesia with a bank classifies on the basis of ownership relationship with Power Center Commercial (Commercial Power Centres - CPC). The results showed that the discipline of the market in Indonesia is still weak because it tends to occur only on the banks of non-CPC. This study concluded that the mechanism of market discipline less effective for developing countries. Differences in the results of this study with Jatna (2007) and Valensi (2005) may be due to differences in the study period, the research object in the form of Islamic banks as well as the different guarantee schemes.

Table 5 Model Summary

\begin{tabular}{|c|c|c|}
\hline Square & Adjusted R Square & Std. Error of the Estimate \\
\hline, 840 &, 835 &, 64831 \\
\hline
\end{tabular}

a. Predictors: (Constant), Y_hat(Unstandardized Predicted Value)

b. Dependent Variable: Z (LnDPK)

\section{Source: data were processed using SPSS ver 20}

Coefficient of determination can be seen in the value of Adjusted R Square (R2) of 0.835 means $\Delta D P K$ (Z) can be explained by the independent variable level of disclosure (Y) amounted to $83.5 \%$. The remaining $16.5 \%(100 \%-83.5 \%)$ is explained by other causes beyond the model. The level of disclosure could reasonably explain $\triangle \mathrm{DPK}$ but there are other factors that affect $\triangle \mathrm{DPK}$.

There are several other factors that can influence the pattern of market discipline in this case $\Delta \mathrm{DPK}$, one of which is data regarding disclosure of bank risk to the public. Arifin et.al (2005) in his study mentioned that the level of risk disclosure Islamic banks is still low and does not depict the actual bank 
risks. Lachrech et.al (2014) describes the importance of Islamic banking standards enforcement transparency. In this case the role of Islamic banking regulatory standards that PAPSI need more emphasis on the disclosure of risks. So that the material can be further study, whether the standard of disclosure contained in PAPSI 2003 also recently PAPSI 2013 has been described the condition of the real risk of Islamic banks?

Basic information is also a determining factor of market discipline, in this view the client's ability to absorb and analyze information that is then used as the basis for decision making. Hasan, et.al (2012) discovered the phenomenon that the actions of depositors is more influenced rumors and Central Bank support directly interpreted as an indication of financial difficulties at the bank. Errors in receipt of this information can lead to errors in decision making. Therefore, absorption and analytical power of customer information needs to be observed further. The critical question that will appear, if the customer can actually take advantage of the performance and risk information has been disclosed by the bank? Or whether the customer actually has to read financial statements of banks and fundamental analysis as a basis for decision making?

Analysis of factors that affect the sensitivity of the customers also need to be an object in next research. Some studies say that deposit insurance can affect the sensitivity of the customer as well as the impact on the market the disciplinary mechanism paper mentioned that besides recommending sufficient level of disclosure, Hosono (2005) sees need a limitation of deposit protection to increase market discipline. Febrian and Herwany (2011) also questioned the sensitivity depositors against bank risk in emerging countries to which it deposits insured by the government or other agency concerned. Just feeling safe, depositors in Indonesia tendency to be indifferent to the risks of Islamic banks and conventional banks for deposits are insured or guaranteed (Febrian and Herwany, 2011).

In other words, deposit insurance can affect the sensitivity of deposan. Although in the context of Islamic banks no fixed return or high risk -yield, the depositors sensitivity will be less if there is a high level of guarantee deposits. This is in line with the opinion of Levy-Yeyati et.al (2004) that the notion of market discipline in developing economies need to take into account the systemic risk that linearly with the level of the deposit guarantee. In Turkey, the revision insurance policy to which it all banks are under the same deposit insurance company, so there is no double element in the guarantee system (Aysan, et.al, 2015).

Other factors such as the level of stability Islamic banks also affect the behavior of customers and market discipline scheme (Gamaginta and Rokhim, 2010). Exploratory factor analysis is performed by Abduh (2011) in detecting the risk of withdrawal of deposits by customers using the approach to quality Islamic banking services with five dimensi. Test of comparison market discipline mechanisms between Islamic banks and conventional banks also need to be studied further, to see the consistency of the results Hasan and Tandelilin (2012) regarding the scheme stronger market discipline on islamic banking.

\section{RESEARCH CONCLUSION, LIMITATION, AND RECOMMENDATION}

\subsection{Conclusion}

The level of disclosure (mandatory and voluntary disclosure) were highest at Bank Syariah Mandiri and Bank Indonesia Muammalat by $71 \%$, while Maybank Syariah is the lowest at $56 \%$. Changes in the number of Third Party Funds $(\triangle \mathrm{DPK})$ were highest at Bank Syariah Mandiri with an average $\Delta \mathrm{DPK}$ amounted to 9.15 trillion rupiah, while the lowest was Maybank Syariah $\triangle D P K$ with an average of 0.21 trillion rupiah. Then from the regression analysis results disclosure level significant positive effect on $\triangle \mathrm{DPK}$, this suggests that the market (customers) to respond the information on the performance and risks of the company through changes in total deposits. In other words happen mechanism of market discipline on Islamic banking in Indonesia in 2011-2014. Contribution of this study is to show the overview of level of disclosure sharia banking in Indonesia which has not been done by previous research. The results of this study could be a matter of evaluation for Islamic banking in order to improve transparency which is provide relevant information to stakeholders for decision making. For the regulator can be input in the formulation of standards (PAPSI) related to the relevance of disclosure risk. 


\subsection{Limitation}

Limitations of this study is data sharia banking in Indonesia is still limited to 11 banks, and this research has not touched the other factors that affect both the market discipline mechanism potentially as control variables, intervening and moderating.

\subsection{Recommendation}

This study still needs to be strengthened by the data disclosure risks and absorption of customer information, analysis of factors that affect the sensitivity of customers, among others; deposit insurance, systemic risk, quality of service Islamic bank, and so on. This research is also necessary to test a comparison with a conventional bank. The importance of these factors can be material for future research related to market discipline.

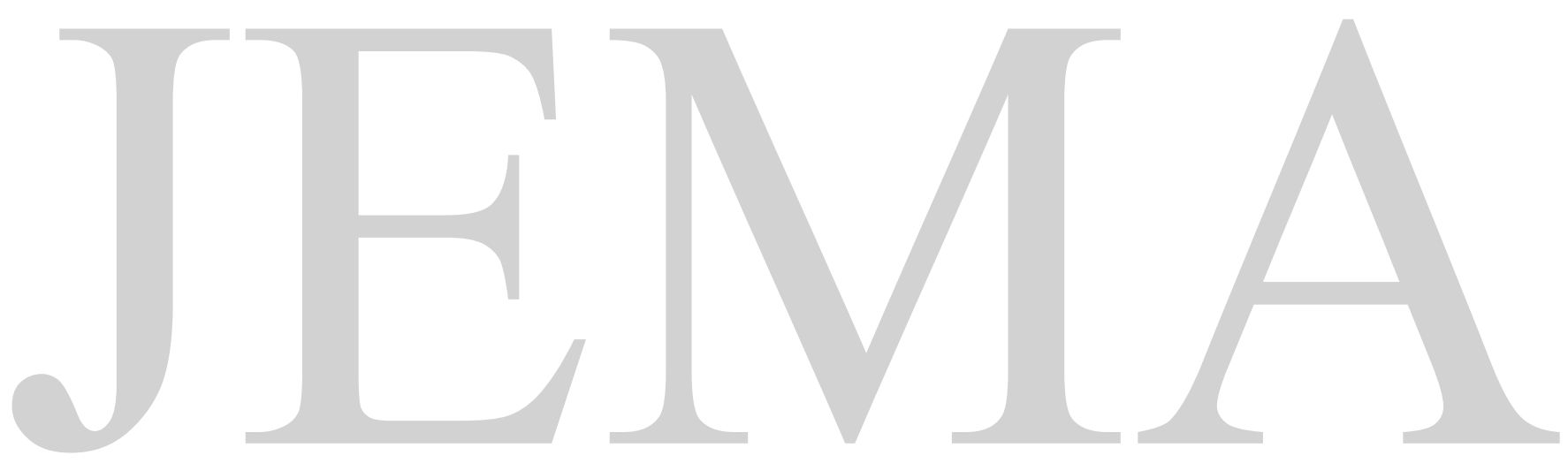


Jurnal Ilmiah Bidang Akuntansi dan Manajemen (JEMA) Vol. 14 No. 1 (2017)

http://riset.unisma.ac.id/index.php/jema

\section{REFERENCES}

Abduh, Muhamad. 2011. Islamic Banking Service Quality and Withdrawal Risk: The Indonesian Experience. International Journal of Excellence in Islamic Banking and Finance. Vol.1, Issue 2, September 2011. ISSN: 2220-8291.

Agustina, Linda. 2012. Pengaruh Karakteristik Perusahaan Terhadap Pengungkapan Laporan Tahunan. Jurnal Dinamika Akuntansi Vol. 4, No. 1, Maret 2012, pp. 55-63. http://journal.unnes.ac.id/index.php/jda.

Al-Baluchi, Ahmed Ebrahim Abdulqader. 2006. The Impact of AAOIFI Standards and Other Bank Charactheristics on The Level of Voluntary Disclosure in The Annual Reports of Islamic Banks. Disertasi. School of Management University of Surrey, Bahrain.

Al-Sawalqa, Fawzi. 2014. Corporate Governance Mechanisms and Voluntary Disclosure Compliance: The Case of Bank in Jordan. International Journal of Academic Research in Accounting, Finance and Management Sciences. Vol. 4, No. 2, April 2014, pp. 373-388. www.hrmars.com

Arifin, Noraini Mohd; Archer, Simon; Karim, Rifaat Ahmed Abdel. 2005. Transparency and Market Discipline in Islamic Bank. islamiccenter.kau.edu.sa

Aysan, Ahmet Faruk; Mustafa Disli; Huseyin Ozturk, Ibrahim M.Turhan. 2015. Are Islamic Banks Subject to Depositor Discipline?The Singapore Economic Review, Vol. 60, No. 1.

Bank Indonesia. 2003. Pedoman Akuntansi Perbankan Syariah Indonesia (PAPSI) Tahun 2003 - Surat Edaran BI No.5/26/BPS Tanggal 27 Oktober 2003. www.bi.go.id

Bank Indonesia. 2014. Outlook Perbankan Syariah 2014. www.bi.go.id

Bank Indonesia. 2009. Peraturan Bank Indonesia Nomor 11/33/PBI/2009. www.bi.go.id

Basel Committee on Banking Supervision. 2001. Working Paper on Pillar 3 -Market Discipline.

Baskaraningrum, Made Ratih \& Ni Ketut Lely A Merkusiwati. 2013. Pengungkapan Sukarela Laporan Keuangan Tahunan dan Faktor-Faktor yang Mempengaruhi (Studi pada Saham-Saham LQ45 di Bursa Efek Indonesia Periode 2010-2011). Jurnal FEB Udayana 2013, pp. 01-19.

Deegan, Craig. 2000. Financial Accounting Theory. New South Wales, Australia: Mc Graw Hill.

Febrian, Erie; Aldrin Herwany. 2011. Depositor Sensitivity to Risk of Islamic and Conventional Banks: Evidence from Indonesia. The International Journal of Business and Finance Research. Vol.5, No. 3.

Freeman, R. Edward. 1984. Strategic Management: A Stakeholder Approach. Boston: Pitman Publishing. ISBN 0-273-01913-9.

Gamaginta dan Rokhim, Rofikoh. 2010. The Stability Comparison between Islamic Banks and Conventional Banks: Evidence in Indonesia. Proceeding at 8th International Conference on Islamic Economics and Finance.

Gray, R; R. Kouhy; dan S. Lavers. 1995. Corporate and Enviromental Reporting. A Review of the Literature and a Longitudinal Study of UK Disclosure. Accounting, Auditing and Accountability Journal, Vol.8, No.2, pp. 47-77.

Hamalainen, Paul; Hall, Maximilian; Howcroft, Barry . 2003. Market Discipline : a Theoritical Framework For Regulatory Policy Developmentdalam Kaufman, George G., Market Discipline in Banking : Theory and Evidence. Elsevier.

Hamalainen, Paul; Hall, Maximilian; Howcroft, Barry . 2005. A framework for Market Discipline in Bank Regulatory Design. Journal of Business, Finance \& Accounting. Vol 32 (1) \& (2), January/ March 2005, pp.183-209. 
Hardiningsih, Pancawati. 2008. Analisis Faktor-Faktor yang Mempengaruhi Voluntary Disclosure Laporan Tahunan Perusahaan. Jurnal Bisnis dan Ekonomi (JBE), Maret 2008, Hal. 67 - 79 Vol. 15, No.1.

Hapsoro, Dody. 2009. Investigation of Factors Influencing Voluntary Disclosure of Financial Information on The Internet by Indonesian Companies. The Indonesian Journal of Accounting Research, Vol. 12, no.3, September 2009, Page: 195-215.

Hasan; Eduardus Tandelilin. 2012. Banking Market Discipline in Indonesia, an Empirical Test on conventional and Islamic Banks. Journal of Indonesian Economy and Business. Vol.27, No.2, May 2012.

Hasan, Iftekhar; Krzysztof Jackowicz; OskarKowalewski; Lukasz Koz lowski. 2012. Market Discipline During Crisis: Evidence from Bank Depositors in Transition Countries. MPRA Paper No.43693. https://mpra.ub.uni-muenchen.de/43693.

Hasan. 2013. Meningkatkan Transparansi dan Disiplin Pasar Perbankan Syariah di Indonesia. Economica, Jurnal Pemikiran dan Penelitian Ekonomi Islam. Vol. IV/Edisi 1/Mei 2013.

Hidayat, Sutan Emir \& Nayla Abdulla Abdulrahman. 2014. An Analysis on Disclosures in the Annual Reports of Islamic Banks in Bahrain. International Journal of Pedagogical Innovations, Vol. 2, No. 1, Jan. 2014, pp. 1-5.

Hosono, Kaoru. 2005. Market Discipline to Banks in Indonesia, the Republic Of Korea, Malaysia and Thailand. Proceeding ADBI Conference 20-21 January 2005.

Jatna, Mardianto. 2007. Pengujian Efektivitas Market Disipline (Disiplin pasar) Pada Bank Umum di Indonesia dengan Balanced Panel Data Estimation. Tesis Magister Manajemen Universitas Gadjah Mada.

Klaus Schwab, World Economic Forum. 2014. The Global Competitiveness Report 2013-2014, Indonesia, pp. 219.

Levy-Yeyati; Eduardo; Maria Soledad Martinez Peria; Sergio L. Schmukler. 2004. Market Discipline under Systemic Risk: Evidence from Bank Runs in Emerging Economics. Working Paper.

Lahrech, Nada; Abdelmounaim Lahrech; Youssef Boulaksil. 2014. Transparency and Performance in Islamic Banking Implications on Profit Distribution. International Journal of Islamic andMiddle Eastern Finance and Management, Vol. 7 No. 1, 2014, pp. 61-88.

Nurhayati, Sri \& Wasilah. 2013. Akuntansi Syariah Di Indonesia, Edisi 3. Seri Departemen Akuntansi FEUI. Jakarta: Salemba Empat.

Nuryaman. 2008. Pengaruh Konsentrasi Kepemilikan, Ukuran Perusahaan, dan Mekanisme Corporate Governance terhadap Pengungkapan Sukarela. The $2^{\text {nd }}$ Accounting Conference, 1 Colloquium, and Accounting Workshop, Depok, 4-5 November 2008, Gov10-1 s/d Gov 10-23 : Bridging the Gap between Theory and Practice.

Oktaviani, Intan Herlina \& Dwi Martani. 2006. Analisis Pengungkapan Laporan Keuangan Perusahaan Pembiayaan. Jurnal Akuntansi dan Keuangan Indonesia, Desember 2006, Vol.3, No. 2, pp.239260.

Permata, Tuidza Indah. 2013. Pengaruh Ukuran Perusahaan, Kepemilikan Saham Publik, dan Likuiditas terhadap Pengungkapan Wajib Laporan Keuangan. Jurnal Ilmiah Wahana Akuntansi, Volume 8, No.2, Tahun 2013, Hal: 118-136.

Primastuti, Sinung \& Tarmizi Achmad. 2012. Pengaruh Corporate Governance Dan Karakteristik Perusahaan Terhadap Luas Pengungkapan Informasi Strategis. Diponegoro Journal of Accounting, 
Volume 1, Nomor 2, Tahun 2012, Halaman 1-15. http:/lejournals1.undip.ac.id/index.php/accounting.

Sekaran, Uma. 2003. Research Methods for Business: A Skill Building Approach, $4^{\text {th }}$ Edition. Prentice Hall International.

Shehata, Nermeen F. 2014. Theories and Determinants of Voluntary Disclosure. Accounting and Finance Research, Vol. 3, No. 1; 2014.

Stephanou, Constantinos. 2010. Rethinking Market Discipline in Banking Lessons from The Financial Crisis. The World Bank Policy Research Working Paper 5227.

Subkhan \& Devi Indah Luthfiyadi. 2011. Faktor yang Mempengaruhi Luas Pengungkapan Wajib Laporan Keuangan pada KPRI di Kudus. Jurnal Dinamika Akuntansi, Vol. 3, No. 1, Maret 2011, pp. 15-22. http://journal.unnes.ac.id/index.php/jda

Sugiyono. 2011. Statistika untuk Penelitian. Bandung: Alfabeta.

Suhardjanto, Djoko \& Rena Rukmita Yulianingtyas. 2011. Pengaruh Karakteristik Pemerintah Daerah terhadap Kepatuhan Pengungkapan Wajib dalam Laporan Keuangan Pemerintah Daerah (Studi Empiris pada Kabupaten/Kota di Indonesia). Jurnal Akuntansi \& Auditing, Volume 8/No. 1/November 2011: 31-42.

Taswan. 2011. Kepemilikan Bank, Kepatuhan Regulasi dan Disiplin Pasar : Kontrol Risiko Perbankan dan Moral Hazard Terkait Posisi Charter Value Pada Periode Penjaminan Simpanan Implisit dan Eksplisit. Ringkasan Disertasi Ujian Terbuka dan Promosi Doktor Fakultas Ekonomika dan Bisnis Universitas Gadjah Mada. Yogyakarta.

Triyuwono, Iwan. 2006. Perspektif, Metodologi, dan Teori: Akuntansi Syariah. Jakarta: PT. Raja Grafindo Persada.

Valensi, Mega. 2005. Who Disciplines Indonesian Banks? a Study of Market Discipline In Indonesia 1980-1999. Thesis for the Doctor of Philosophy of Department of Accounting and Finance Faculty of Business and Economics Monash University. Australia.

Wallace, R.S. Olusegun; Kamal Naser dan Araceli Mora. 1994. The Relationship between The Comprehensiveness of Corporate Annual Reports and Firm Characteristics in Spain, Accounting and Bussiness Research, Vol. 25, No. 97, pp. 41-53.

Wardani, Rr. Puruwita. 2012. Faktor-Faktor yang Mempengaruhi Luas Pengungkapan Sukarela. Jurnal Akuntansi dan Keuangan, Vol.14, No.1, Mei 2012, pp. 1-15.

*) Ayub Wijayati Sapta Pradana, University Islam of Malang

**) Hariri, University Islam of Malang

***) Junaidi, University Islam of Malang 


\section{Appendix}

Appendix 1 Items of Mandatory Disclosure

\begin{tabular}{|c|l|c|}
\hline No. & \multicolumn{1}{|c|}{ Items of Informations } & $\sum$ \\
\hline 1. & Chapter II - Financial Statement of Islamic Bank & 34 \\
\hline 2. & Chapter III - Assets & 127 \\
\hline 3. & Chapter IV - Liability & 39 \\
\hline 4. & Chapter V - Investment & 6 \\
\hline 5. & Chapter VI - Equity & 14 \\
\hline 6. & Chapter VII - Income Statements & 14 \\
\hline 7. & Chapter VIII - Cash Flows & 1 \\
\hline 8. & Chapter IX - Changes of Equity Statements & 7 \\
\hline 9. & $\begin{array}{l}\text { Chapter X - Changes of Restricted Fund Statements } \\
\text { (Mudharabah Muqayyadah) }\end{array}$ & 6 \\
\hline 10. & $\begin{array}{l}\text { Chapter XI - Source and Use of ZIS Funds Statement } \\
\text { (Zakat, Infaq, Shadaqah) }\end{array}$ & 3 \\
\hline 11. & $\begin{array}{l}\text { Chapter XII - Source and Use of Qardh Funds } \\
\text { (Qardhul Hasan) }\end{array}$ & $\mathbf{3 6 9}$ \\
\hline 12. & Bagian XIII - Notes to Financial Statements \\
\hline \multicolumn{2}{|c|}{ Amount Items of Mandatory Disclosure } \\
\hline
\end{tabular}

Source: PAPSI 2003

Appendix 2 Items of Voluntary Dsiclosure

\begin{tabular}{|c|l|c|}
\hline No. & \multicolumn{1}{|c|}{ Items of Information } & Jumlah Item \\
\hline 1. & General Information of Company & 15 \\
\hline 2. & Reporting & 4 \\
\hline 3. & Information of Financial Statements & 17 \\
\hline 4. & Information of Notes to Financial Statements & 35 \\
\hline \multicolumn{2}{|r|}{ Amount Items of Voluntary Disclosure } & $\mathbf{7 1}$ \\
\hline
\end{tabular}

Source: Al-Baluchi (2006) 
Jurnal Ilmiah Bidang Akuntansi dan Manajemen (JEMA) Vol. 14 No. 1 (2017)

http://riset.unisma.ac.id/index.php/jema

Appendix 3 Unit of Analysis of Islamic Banks in Indonesia

\begin{tabular}{|c|c|}
\hline No. & Name of Islamic Banks \\
\hline 1 & Bank Syariah Mandiri \\
\hline 2 & Bank Mega Syariah \\
\hline 3 & Bank BNI Syariah \\
\hline 4 & Bank BRI Syariah \\
\hline 5 & Bank Muamalat Indonesia \\
\hline 6 & Bank BJB Syariah \\
\hline 7 & Bank Panin Syariah \\
\hline 8 & Bank Bukopin Syariah \\
\hline 9 & Bank Victoria Syariah \\
\hline 10 & Bank BCA Syariah \\
\hline 11 & Bank Maybank Syariah \\
\hline 12 & Bank BTPN Syariah \\
\hline
\end{tabular}

Source: Otoritas Jasa Keuangan (2015)

Appendix 4 Graph of Islamic Banks Disclosure Index 2011-2014

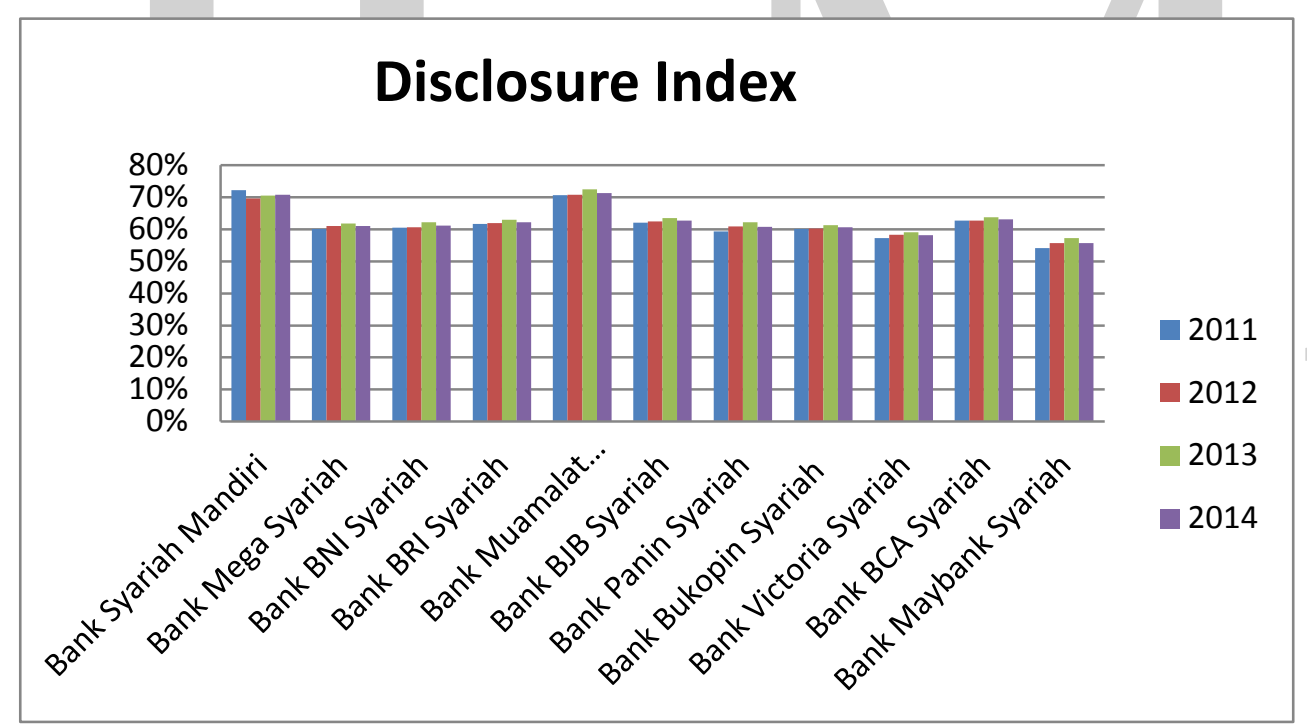

Source: Data is processed from Islamic Banks Annual Report 


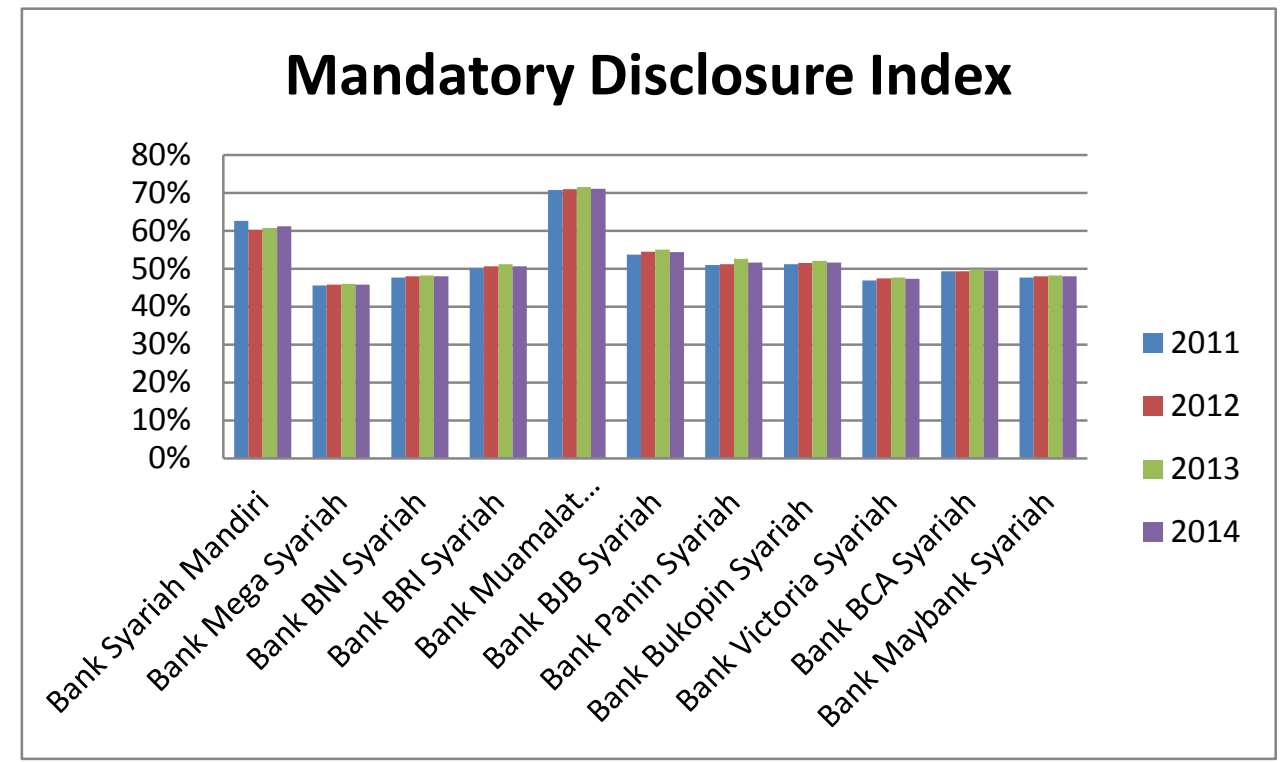

Source: Data is processed from Islamic Banks Annual Report

Appendix 6 Graph of Islamic Banks Voluntary Disclosure Index 2011-2014

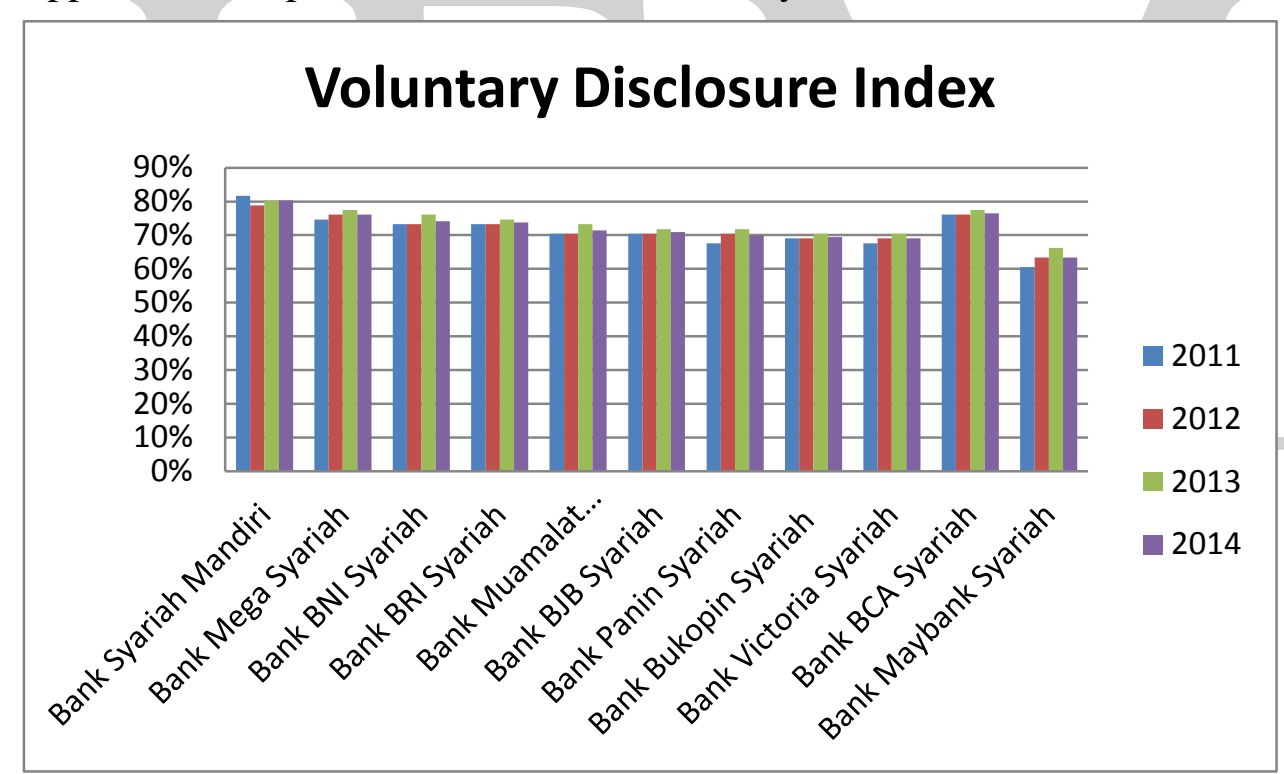

Source: Data is processed from Islamic Banks Annual Report 


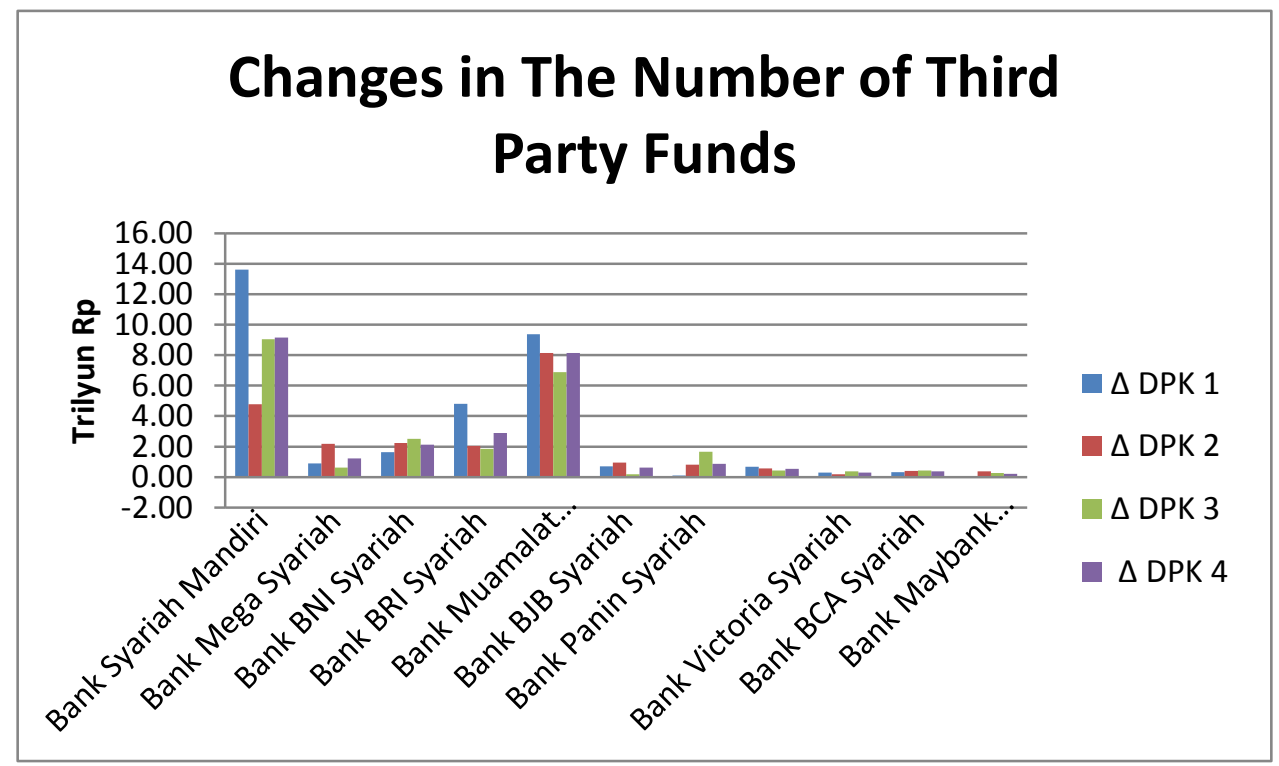

Source: Data is processed from Islamic Banks Annual Report

Appendix 8 Normality Test Results

\section{One-Sample Kolmogorov-Smirnov Test}

\begin{tabular}{|ll|r|}
\hline & & \multicolumn{2}{|c|}{$\begin{array}{c}\text { Unstandardized } \\
\text { Residual }\end{array}$} \\
\hline $\mathrm{N}$ & Mean & 33 \\
Normal Parameters & Stb & $0 \mathrm{E}-7$ \\
& Std. & 2,33737320 \\
Most Extreme & Deviation &, 098 \\
Differences & Absolute &, 082 \\
Kolmogorov-Smirnov Z & Positive &,- 098 \\
Ksymp. Sig. (2-tailed) & Negative &, 562 \\
Asy &, 911 \\
\hline
\end{tabular}

a. Test distribution is Normal.

b. Calculated from data.

Criteria:

Sig. $>\alpha \rightarrow$ data is normally distributed

Sig. $<\alpha \rightarrow$ data is abnormally distributed

Source: Data processed using SPSS ver 20 
Jurnal Ilmiah Bidang Akuntansi dan Manajemen (JEMA) Vol. 14 No. 1 (2017)

http://riset.unisma.ac.id/index.php/jema

Appendix 9 Normality Test Chart - Normal P Plot

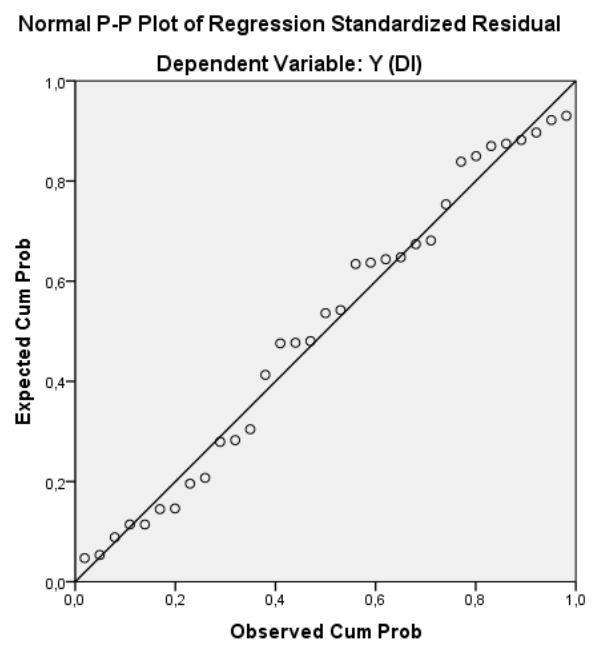

Source: Data processed using SPSS ver 20

Appendix 10 Graph of Heteroscedasticity Results

Scatterplot

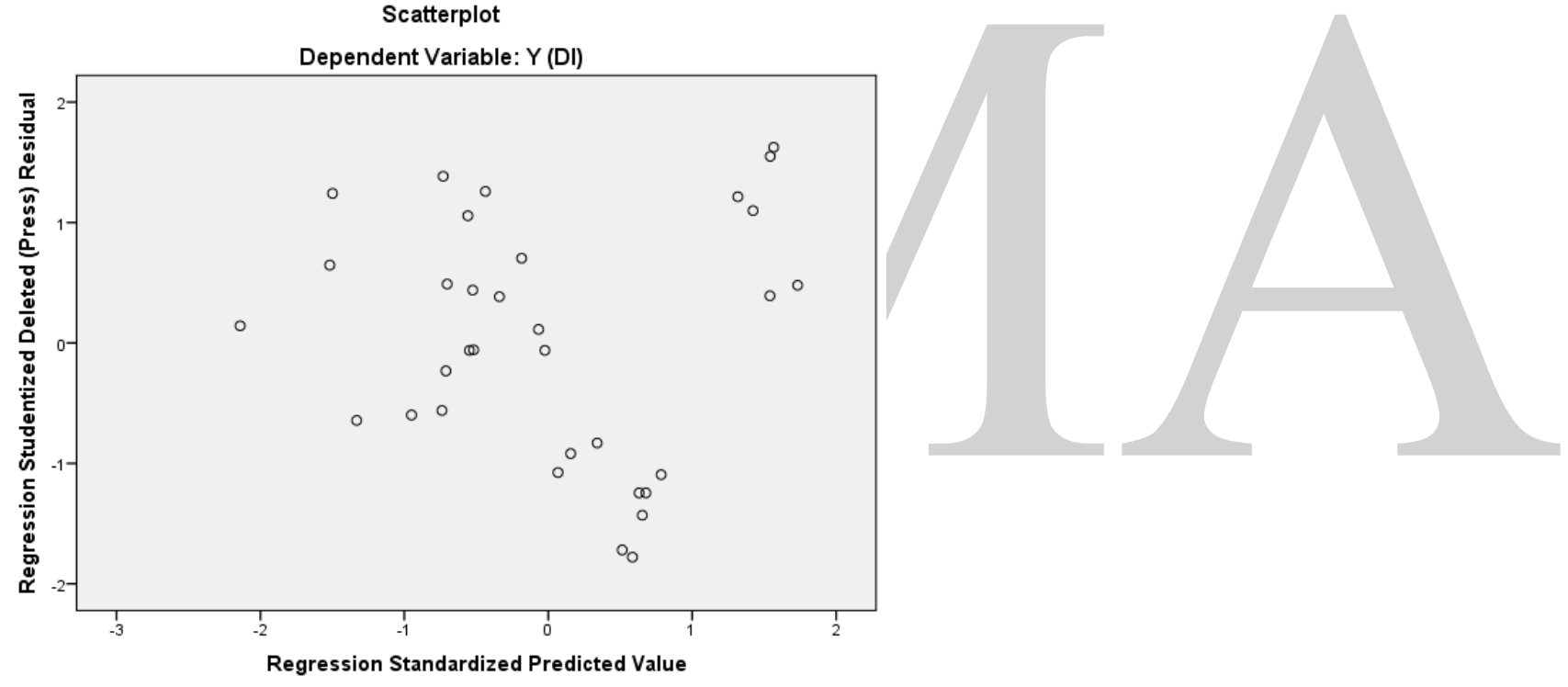

Source: Data processed using SPSS ver 20 
Jurnal Ilmiah Bidang Akuntansi dan Manajemen (JEMA) Vol. 14 No. 1 (2017)

http://riset.unisma.ac.id/index.php/jema

Appendix 11 Autocorrelation Results - Durbin Watson

Model Summary ${ }^{b}$

\begin{tabular}{|c|c|c|c|c|c|c|c|c|c|c|}
\hline \multirow[t]{2}{*}{ Model } & \multirow[t]{2}{*}{$\mathrm{R}$} & \multirow{2}{*}{$\begin{array}{c}\mathrm{R} \\
\text { Square }\end{array}$} & \multirow{2}{*}{$\begin{array}{l}\text { Adjusted } \\
\text { R Square }\end{array}$} & \multirow{2}{*}{$\begin{array}{l}\text { Std. Error } \\
\text { of the } \\
\text { Estimate }\end{array}$} & \multicolumn{5}{|c|}{ Change Statistics } & \multirow{2}{*}{$\begin{array}{c}\text { Durbin } \\
- \\
\text { Watso } \\
n\end{array}$} \\
\hline & & & & & $\begin{array}{c}\text { R Square } \\
\text { Change }\end{array}$ & $\begin{array}{c}\mathrm{F} \\
\text { Change }\end{array}$ & df1 & df2 & $\begin{array}{l}\text { Sig. F } \\
\text { Chan } \\
\text { ge }\end{array}$ & \\
\hline 1 & $\begin{array}{r}, 863 \\
a\end{array}$ &, 745 & ,708 & 2,49876 & ,745 & 20,424 & 4 & 28 & ,000 & 1,691 \\
\hline
\end{tabular}

a. Predictors: (Constant), X4 (FDR), X1 (Ln aset), X2 (DER), X3 (ROA)

b. Dependent Variable: Y (DI)

Source: Data processed using SPSS ver 20

Appendix 12 Results of Autocorrelation Decission

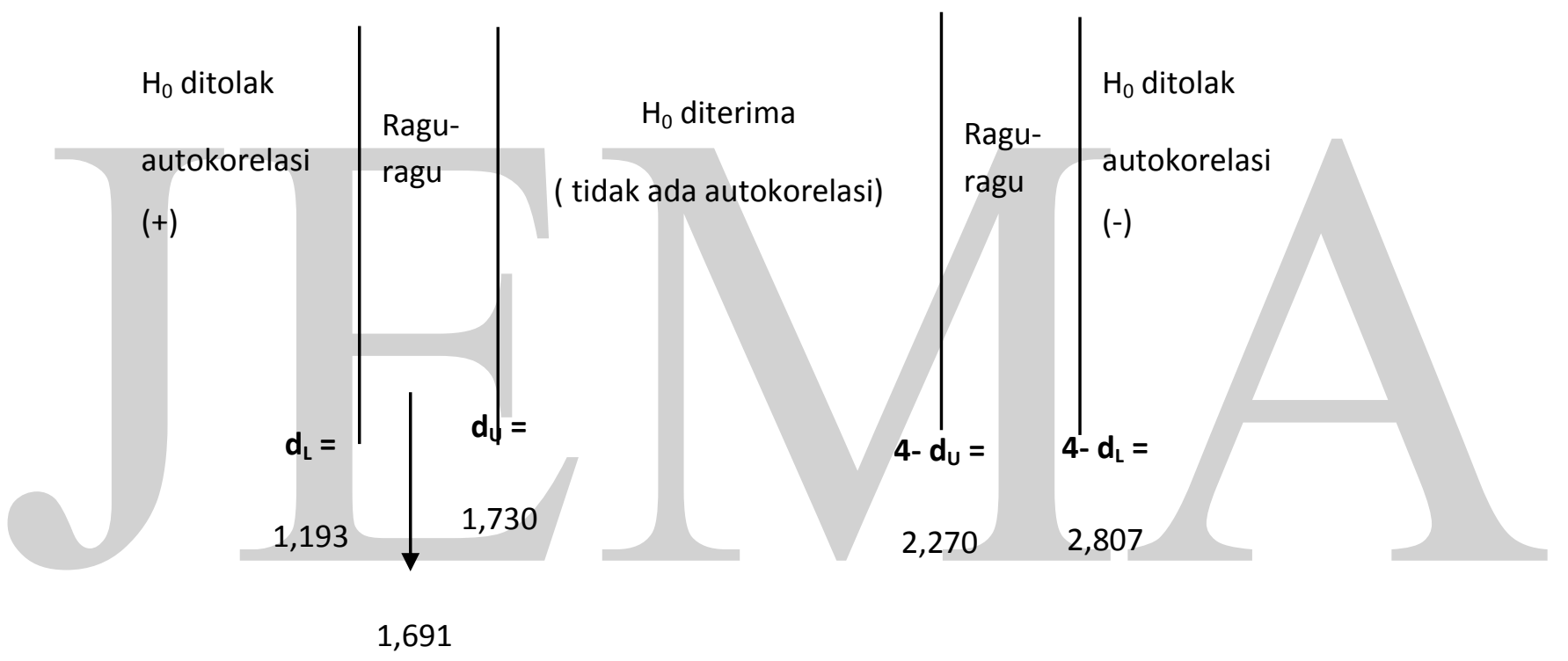


Jurnal Ilmiah Bidang Akuntansi dan Manajemen (JEMA) Vol. 14 No. 1 (2017)

http://riset.unisma.ac.id/index.php/jema

Appendix 13 Autocorrelation Results - Run Test

\section{Runs Test}

\begin{tabular}{|l|r|}
\hline & \multicolumn{2}{|c|}{$\begin{array}{c}\text { Unstandardized } \\
\text { Residual }\end{array}$} \\
\hline Test Value &, 22743 \\
Cases $<$ Test Value & 16 \\
Cases $>=$ Test Value & 17 \\
Total Cases & 33 \\
Number of Runs & 18 \\
$Z$ &, 005 \\
Asymp. Sig. (2-tailed) &, 996 \\
\hline
\end{tabular}

a. Median

Source: Data processed using SPSS ver 20

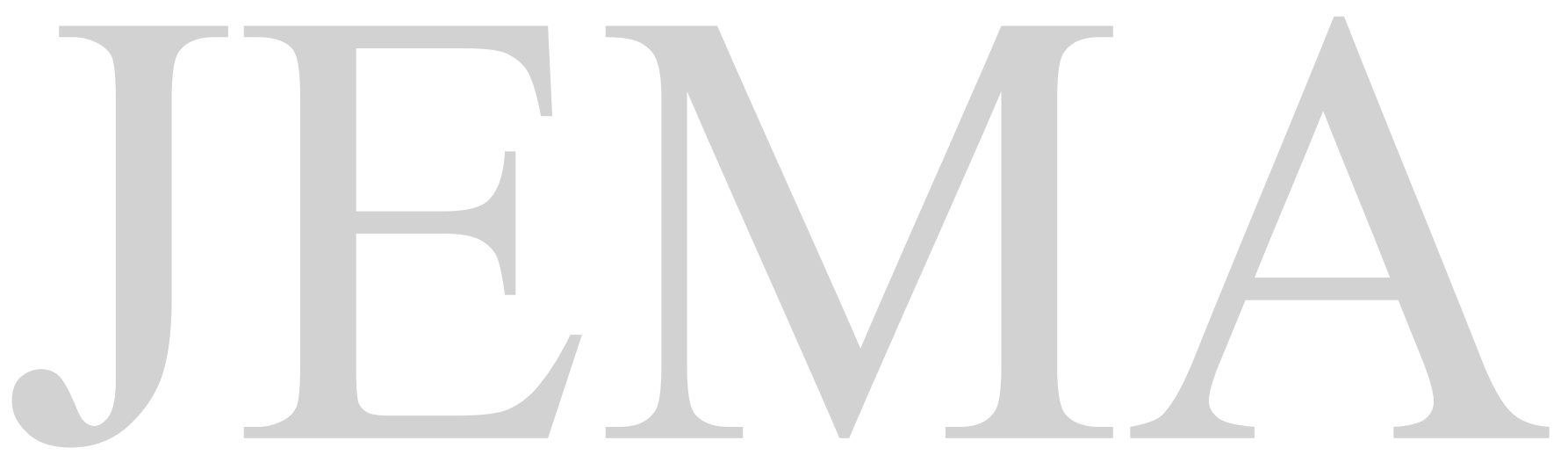

